\title{
A New Model for the Transmission of Helicobacter pylori: Role of Environmental Reservoirs as Gene Pools to Increase Strain Diversity
}

\author{
N. F. Azevedo \\ IBB - Institute for Biotechnology and Bioengineering, Centre for Biological Engineering, \\ Universidade do Minho, Campus de Gualtar 4710-057, Braga, Portugal; School of Biological Sciences, \\ University of Southampton, United Kingdom
}

\section{N. Guimarães}

IBB - Institute for Biotechnology and Bioengineering, Centre for Biological Engineering, Universidade do Minho, Campus de Gualtar 4710-057, Braga, Portugal; IPATIMUP_Institute of Molecular Pathology and Immunology of the University of Porto, Porto, Portugal

\section{Figueiredo}

IPATIMUP_Institute of Molecular Pathology and Immunology of the University of Porto, Porto, Portugal; Medical Faculty of Porto, Porto, Portugal

\author{
C. W. Keevil \\ School of Biological Sciences, University of Southampton, United Kingdom
}

\author{
M. J. Vieira \\ IBB - Institute for Biotechnology and Bioengineering, Centre for Biological Engineering, \\ Universidade do Minho, Campus de Gualtar 4710-057, Braga, Portugal
}

Twenty-five years after the first successful cultivation and isolation of Helicobacter pylori, the scientific community is still struggling to understand the way(s) this bacterium is transmitted among the human population. Here, both epidemiologic and microbiologic evidence addressing this matter is reviewed and explored to conclude that most $\boldsymbol{H}$. pylori successful colonizations are derived from direct person-to-person contact and that even though exposure of humans to $\mathrm{H}$. pylori from environmental sources is a very common event, in most occasions the host is able to fight off infection. In addition, under a new model developed here, we propose that the near elimination of environmental reservoirs is the main responsible for the lower prevalence observed in the more industrialized countries by acting on two levels: by decreasing the number of direct infections and by diminishing the number of intraspecies recombination events for producing strain variation within $H$. pylori.

Keywords Helicobacter pylori; Epidemiology; Microbiology; Water
Helicobacter pylori is a Gram-negative $\varepsilon$-proteobacterium closely related to Campylobacter spp. It has now been well established that infection of the human host with this microorganism is a risk factor for the development of gastric-related diseases (reviewed in Malfertheiner et al. 2006). In fact, much of the research on $H$. pylori has been concerned with the determination of its role in human condition and on the identification and characterization of virulence factors that contribute to disease development (e.g., Blaser and Atherton 2004; Prinz, Hafsi, and Voland 2003; Figueiredo, Machado, and Yamaoka 2005).

Other issues that have been receiving a great deal of attention are the prevalence and epidemiology of infection (e.g., Kikuchi and Dore 2005; Queiroz and Luzza 2006; Brown 2000). The first one is essential to understand the extent of the problem for human populations, whereas the second tries to relate presence of infection with a number of factors that are relevant for acquisition. Even though these types of studies provide a good indication on how a microorganism is transmitted, they usually require subsequent confirmation. In general, verification can be accomplished by using microbiological techniques to grow and isolate the microorganism from suspected reservoirs. However, the latter has failed to provide definitive conclusions on the suspected routes 
and vehicles of transmission, a situation that can be explained by some unique features of $H$. pylori interaction with human individuals and the bacterium's physiology. For instance, infection of the bacterium usually goes by unnoticed for the entire life of the host, and even when it causes health concerns, first symptoms generally take a long time to occur after infection (Brown 2000). This implies that small episodes of transmission and even possible outbreaks of the bacterium, if any, would be unnoticed by public health authorities. Another hindering aspect is that $H$. pylori is relatively complicated to isolate from any natural system (except for the human gastrointestinal tract) under currently used culture media (Andersen and Wadstrom 2001), especially if the environment houses other bacteria. Whether the bacterium enters or not a viable but non-culturable (VBNC) state is a matter of discussion (Chaput et al. 2006; Bumann et al. 2004), and even more debatable is if under stressful conditions the bacterium can infect the human host. Addressing all these issues is of extreme importance, as they may lead to the development of prophylactic measures to decrease the prevalence observed across the world.

This review will start by indicating prevalence levels of H. pylori in the human population. Then, possible routes of transmission will be described, together with the presentation of both epidemiological and microbiological data supporting or dismissing each individual route. Finally, a discussion based on the evidence provided will conclude about the most likely routes of transmission, develop a model to explain the observed decrease in prevalence in industrialized countries and suggest what needs to be performed in order to advance our understanding.

\section{PREVALENCE OF $\boldsymbol{H}$. pylori ACROSS THE WORLD}

H. pylori infection occurs worldwide, but significant differences in prevalence have been found both within and between countries (Mitchell 2001). Generally, the overall prevalence is higher in countries of underdeveloped regions, such as Africa and Asia, than in the more developed countries in Western Europe and North America (Figure 1). Overall, H. pylori prevalence is decreasing as a result of improved sanitary conditions and treatment procedures (Rehnberg-Laiho et al. 2001).

It is now well known that $H$. pylori infection is mostly acquired in childhood, and that by the age of 10 more than $50 \%$ of children worldwide carry the organism (Pounder and Ng 1995). In addition, adults might also acquire infection but at much lower rates (Kivi and Tindberg 2006). A number of studies have suggested that transient infections might occur and even be quite common (e.g., Goodman et al. 2005; Haggerty et al. 2005), but the significance of these results are still under dispute due to the specificity and sensitivity of the tests used (Perry and Parsonnet 2005; Nugalieva, Opekun, and Graham 2006). Recent evidence has also showed that multiple $H$. pylori strains and other Helicobacter spp. are able to infect simultaneously the GI tract of one individual (Van den Bulck et al. 2005; Fritz et al. 2006; De Gusmao et al. 2000; Daugule et al. 2003; Ghose et al. 2005; Kang and Blaser 2006; Israel et al. 2001). Even in cases where multiple strains may occur as a result of intensive genetic recombination of a single ancestral strain, it is recognized that the ancestor had to be in contact with other strains (Delport et al. 2006).
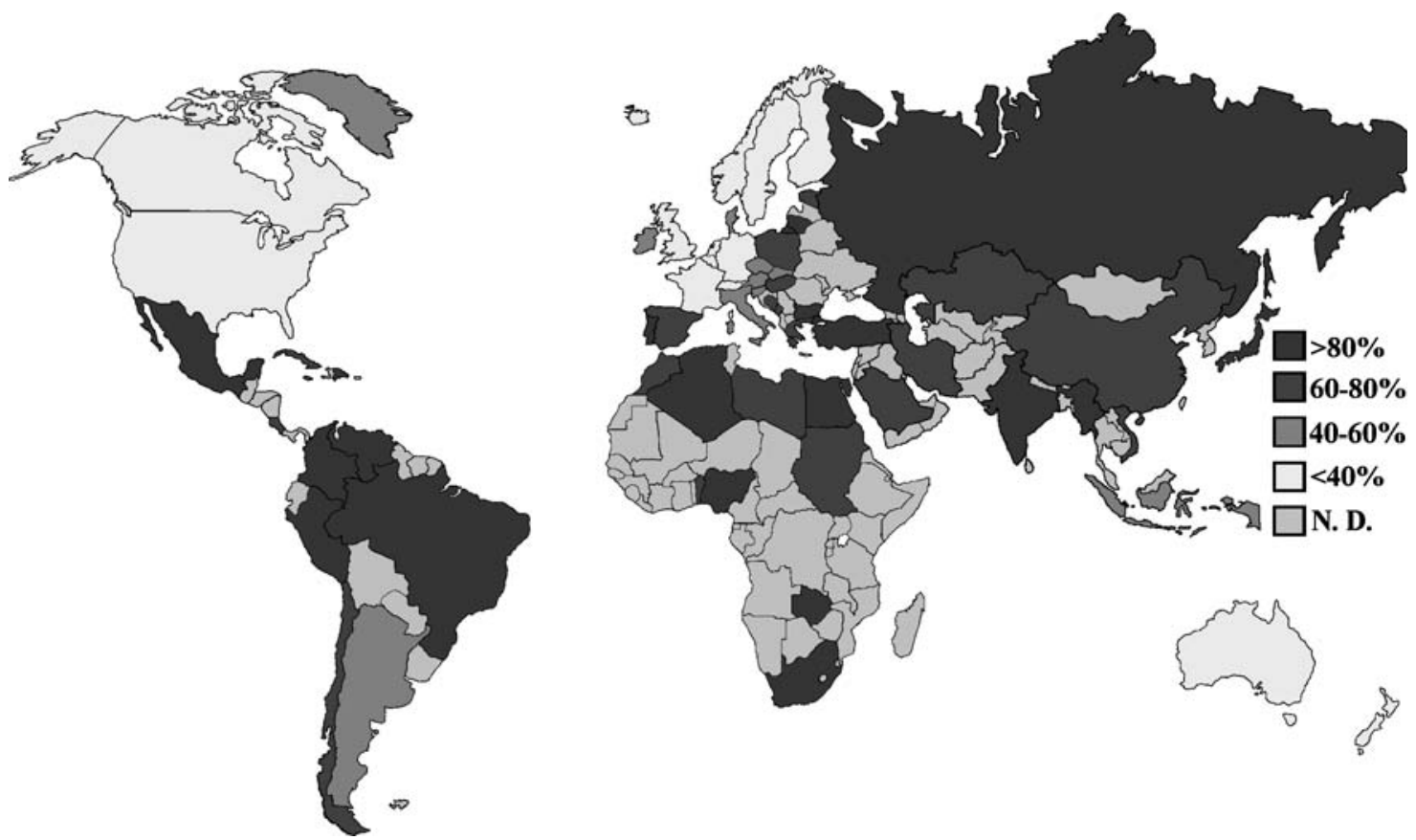

FIG. 1. Prevalence of $H$. pylori in human populations worldwide. The map was based on data collected by Lunet et al. (Lunet and Barros 2003) and completed with other studies (Torres et al. 2003; Nurgalieva et al. 2002; Bakka and Salih 2002; Erreimi et al. 1999; Boyanova et al. 1994; Koch et al. 2005; Con et al. 2006; Carrillo et al. 2005; Carrillo 2005; Hoodeh et al. 2005; Aguemon et al. 2005; Hoang et al. 2005; Vollaard et al. 2006). The criteria used for the selection of new studies is also described in (Lunet and Barros 2003). N. D. stands for places where a consistent study about $H$. pylori prevalence has not yet been conducted. 
In accordance with these data, the classical scenario where the host is generally exposed only once to the bacterium, but where colonization is usually successful appears to be losing ground to a scenario where there is constant exposure to $H$. pylori but where the balance between the host and the bacterium tends to favor the elimination of the microorganism or the colonization by multiple strains. This latter scenario implies that the decreasing levels of $H$. pylori in the human GI tract observed in developed countries are not due to a decreasing number of exposure events between the microorganism and the host but instead to increased resistance of the host to the bacterium or "less fit" $H$. pylori in contact with the host.

\section{ROUTES OF INFECTION}

Numerous epidemiological studies have been conducted to identify the factors influencing transmission of this pathogen. Socioeconomic status is clearly the most important determinant for the development of $H$. pylori infection, with poorer/lower social classes exhibiting much higher prevalence (Mitchell 2001), which is also in accordance with differences found between underdeveloped and developed countries described in the previous section. This factor encompasses conditions such as levels of hygiene, density of living, sanitation, and educational opportunities, which have all been individually identified as markers of the bacterium presence.

Largely based on epidemiological and microbiological evidence, several routes of transmission have been conjectured (Figure 2). Person-to-person transmission is widely seen as the most probable route of infection, mainly because of the apparent failure to consistently isolate $H$. pylori in places other than the human GI tract and of the perception that lower transit time between different hosts would certainly be favorable for the bacterium. Furthermore, numerous epidemiological studies have consistently identified domestic overcrowding and infection of family members as a risk factor for $H$. pylori transmission. Roma-Giannikou and colleagues (2003) found a strong homol-

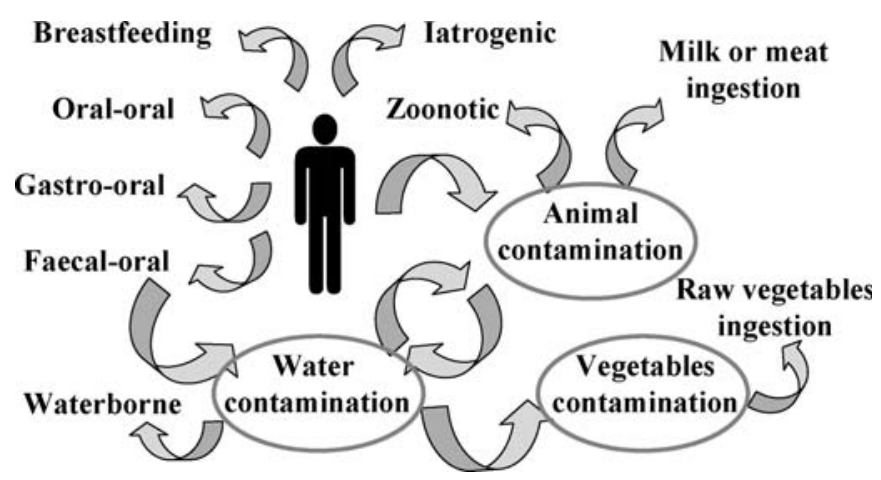

FIG. 2. Suggested transmission routes for $H$. pylori. Five of the proposed pathways are representative of direct person-to-person transmission (breastfeeding, iatrogenic, oral-oral, gastro-oral, and fecal-oral), whereas the remaining four require an environmental reservoir in between. Possible reservoirs outside the human host are marked with a red circle. ogy of the H. pylori genome in infected members of the same family, and clustering of $H$. pylori infection in families has been widely reported in other studies (e.g., Ma et al. 1998). Although these studies support the hypothesis of person-to-person transmission, exposure of a family to an alternative common source still remains a possibility.

The most relevant pathways of person-to-person transmission encompass the gastro-oral, oral-oral, and fecal-oral routes. Breastfeeding and iatrogenic transmission are also included as alternative ways for the dissemination of the pathogen. In addition, there are at least three possible vectors that have been suggested to sustain the bacterium in viable form: water, food, and animals. Most authors agree that the relative importance of these routes in the transmission of the bacterium is likely to vary between developing and developed countries (Perez-Perez, Rothenbacher, and Brenner 2004; Megraud 2003). The most relevant in overall terms are now addressed in detail.

\section{Gastro-Oral Transmission}

It has been suggested that exposure to microscopic droplets of gastric juice during endoscope manipulation could explain an higher prevalence of infection in gastrointestinal endoscopists (Hildebrand et al. 2000), but the gastro-oral transmission has been postulated mainly for young children, among whom vomiting and gastro-esophageal reflux are common. In a recent epidemiological study, exposure to an infected household member with gastroenteritis and vomiting episodes was associated with a 6.3 fold increased risk of new infection (Perry et al. 2006). It is important to realize, however, that because vomiting episodes might cause an increased risk of the presence of $H$. pylori in the oral cavity, this type of study does not discriminate whether the transmission is gastro-oral or oral-oral.

In a study by Parsonnet et al. (Parsonnet, Shmuely, and Haggerty 1999), vomitus from infected subjects and surrounding air were sampled for $H$. pylori. All vomitus samples were positive (often recovering the bacterium in high quantities), and even the surrounded air tested positive for $37.5 \%$ of the cases. Successful cultivation of $H$. pylori from vomitus was also obtained in two other studies (Leung et al. 1999; Young et al. 2000). Amazingly, there is a blatant lack of data on the sur$\mathrm{vival} / \mathrm{culturability}$ time of the bacterium in gastric juice, and as such, it is not possible to estimate for how long the infectious state might last on these conditions and to establish comparisons with culturability times obtained for other conditions.

On the other hand, the discovery of enterohepatic Helicobacter species might challenge the importance of a gastro-oral (and an oral-oral) route (Solnick and Schauer 2001). As the name suggests, these bacteria have been identified in the intestinal tract and/or the liver of humans, other mammals, and birds, which implies a more unlikely presence for them in the oral cavity and stomach. How these bacteria are transmitted is something that has been little studied, but most works appear to support a fecaloral route (Livingston et al. 1998; Bohr et al. 2006; Fox et al. 1992). The question to be asked here is whether the phylogenetic 
proximity to $H$. pylori would imply that transmission routes are similar.

\section{Oral-Oral Transmission}

The oral cavity has been considered to be a suitable reservoir for $H$. pylori subsistence, and oral-oral transmission has therefore been suggested to occur with kissing or other contact with infected saliva, the use of chopsticks by Chinese immigrants or, as it happens in some ethnic backgrounds, from mothers to their babies as they pre-masticate their food. The role of the oral cavity has been extensively reviewed by others (Megraud 1995; Dowsett and Kowolik 2003; Luman 2002), and as such, we will only update information and state the most relevant conclusions. Identical strains of the pathogen have been detected by polymerase chain reaction (PCR) in the mouth and stomach of symptomatic infected individuals (Khandaker et al. 1993), and in these populations detection of $\mathrm{H}$. pylori in the oral cavity by PCR is in fact very common (Dowsett and Kowolik 2003). Nevertheless, studies conducted afterwards using similar techniques indicated that the oral cavity does not favor prolonged colonization of $H$. pylori in populations with high prevalence of infection when the individuals are asymptomatic, and concluded that colonization of the mouth is only transient and occurs after vomiting (Dowsett and Kowolik 2003; Olivier et al. 2006). Similarly, isolation and cultivation of the microorganism has been sporadic and related to transitory regurgitations of the microorganism from the stomach into the mouth (Dowsett and Kowolik 2003; Luman 2002). Microbiological studies on the culturability of $H$. pylori on a buffer containing a peroxidase system with high concentrations of $\mathrm{H}_{2} \mathrm{O}_{2}$ (to simulate saliva), showed that after 1 hour at $37^{\circ} \mathrm{C}$ the bacterium started to be inhibited, but this inhibition was not noticed when the buffer system was added to real human saliva (Haukioja et al. 2004). Luman et al. compared the genotypes of $H$. pylori isolated from patients and their spouses by PCR-restriction fragment length polymorphism and found very little similarity (Luman et al. 2002). It is however possible that several mechanisms, such as point mutations and intragenic recombination, could enhance strain diversity once the infection is acquired.

\section{Fecal-Oral Transmission}

It has been suggested that the fecal-oral route for $H$. pylori transmission is very unlikely due to the contact with human bile, to which it is very sensitive, during the passage through the intestine (Hanninen 1991; Mitchell et al. 1992). One epidemiological study appears to support the view that this transmission mode is less common than gastro-oral or oral-oral, by showing that exposure to an infected household member with diarrhea elevated, but not significantly, the risk for new infection (Perry et al. 2006).

However, the fact that $H$. pylori is able to colonize the duodenum (upper part of the small intestine) in areas of gastric metaplasia, appears to be an inconsistency, and has raised some questions about the exact effect of the passage of the microorganism through the intestine (Han et al. 1996). Well-established detection methods based on PCR or enzyme-linked immunoassays systematically identify the presence of the microorganism (e.g., Ndip et al. 2004; Kabir 2001; Notarnicola et al. 1996; Queralt, Bartolome, and Araujo 2005), but growth of the bacterium using culture methods has been more elusive, and achieved most of the times in individuals with accelerated gut transit time (Luman 2002; Dowsett and Kowolik 2003).

\section{Breastfeeding}

The detection by PCR of H. pylori in breast milk has also raised the possibility of breastfeeding as a route of transmission (Kitagawa et al. 2001), even though earlier studies stated that infants born from $H$. pylori-positive women are not more likely to acquire the infection (Blecker et al. 1994). The contamination of milk could be possible if the bacterium survived in nipples or fingers. However, most epidemiological studies appear not to find any correlation between breastfeeding and $H$. pylori acquisition (Table 1). In fact, a few of them actually mention breastfeeding as a protection practice against the microorganism (Pearce et al. 2005; Ertem, Harmanci, and Pehlivanoglu 2003; Malaty et al. 2001). Survival studies indicate that the bacterium remains culturable in commercial pasteurized milk for 5 days at $4^{\circ} \mathrm{C}$ and an inoculum concentration of $\approx 10^{4} \mathrm{CFU} / \mathrm{mL}$ (Poms and Tatini 2001). It is likely, however, that this relatively long time of survival is related to the low temperatures at which the experiment was carried out.

\section{latrogenic Transmission}

Acquisition of $H$. pylori by patients submitted to upper endoscopy, i.e., iatrogenic transmission, is supported by three out of four epidemiological studies (Table 1). This value of $75 \%$ should nevertheless be interpreted with care as in all but one study, the population that was followed was medical staff from gastrointestinal endoscopy units and as shown above, this group might acquire infection by, for instance, the gastro-oral route and not by direct contact with endoscopes. H. pylori has been consistently detected by culture in endoscopes after their use in infected patients (Nurnberg et al. 2003; Brown et al. 2005; Katoh et al. 1993), but adequate disinfection procedures are thought to greatly reduce (or even eliminate) the transmission risk for this microorganism (Cronmiller et al. 1999). Back in 1995, Tytgat estimated a transmission frequency of approximately 4 patients per 1000 endoscopies when the infection rate in the endoscoped population was about 60\% (Tytgat 1995).

\section{Zoonotic Transmission}

Including contact with animals as a possible transmission mode is an obvious reasoning, as zoonotic transmission represents one of the leading causes of illness and death from infectious disease worldwide. As indicated in Table 1, most epidemiological studies appear to support the role of animals in the 
TABLE 1

Number and percentage of epidemiological studies that considered certain routes of transmission as risk factors, together with survival data of the bacterium for each of the pathways

\begin{tabular}{|c|c|c|c|c|}
\hline $\begin{array}{l}\text { Type of } \\
\text { transmission }\end{array}$ & $\begin{array}{l}\text { Positive } \\
\text { association }^{a}\end{array}$ & $\operatorname{Ref}(s)$ & $\begin{array}{l}\text { H. pylori } \\
\text { survival data }^{c}\end{array}$ & $\operatorname{Ref}(s)$ \\
\hline Gastro-oral & $>100(100 \%)^{e}$ & $\begin{array}{l}\text { (e.g., Rodrigues et al. 2004; Lin et al. } \\
\text { 1999; Rothenbacher et al. 1999) }\end{array}$ & $\begin{array}{l}\text { Spiking experiments not } \\
\text { available. }\end{array}$ & - \\
\hline Oral-oral & & & $\begin{array}{l}\text { It remains culturable for at } \\
\text { least } 1 \text { hour at } 37^{\circ} \mathrm{C} \text {. }\end{array}$ & (Haukioja et al. 2004) \\
\hline Fecal-oral & & & $\begin{array}{l}\text { Spiking experiments not } \\
\text { available. }\end{array}$ & - \\
\hline Iatrogenic & $3(75 \%)^{b}$ & $\begin{array}{l}\text { (Goh, Parasakthi, and Ong 1996; Wu } \\
\text { et al. 1996; Mastromarino et al. } \\
\text { 2005; Noone, Waclawski, and Watt } \\
\text { 2006) }\end{array}$ & $\begin{array}{l}\text { Endoscopes challenged } \\
\text { with } 10^{8} \mathrm{CFU} / \mathrm{mL} \text { were } \\
\text { still contaminated after } \\
\text { manual cleaning but not } \\
\text { after disinfection. }\end{array}$ & (Cronmiller et al. 1999) \\
\hline Breastfeeding & $1(17 \%)$ & $\begin{array}{l}\text { (Malaty et al. 2001; Rothenbacher, } \\
\text { Bode, and Brenner 2002; Ertem, } \\
\text { Harmanci, and Pehlivanoglu 2003; } \\
\text { Pearce et al. 2005; Nguyen et al. } \\
\text { 2006; Rodrigues et al. 2006) }\end{array}$ & $\begin{array}{l}\text { Culturable in pasteurized } \\
\text { milk for } 5 \text { days at } 4^{\circ} \mathrm{C} \text {. }\end{array}$ & (Poms and Tatini 2001) \\
\hline Zoonotic & $7(64 \%)^{d}$ & $\begin{array}{l}\text { (Goodman et al. 1996; Lindo et al. } \\
\text { 1999; Jimenez-Guerra, Shetty, and } \\
\text { Kurpad 2000; Herbarth et al. 2001; } \\
\text { Plonka et al. 2006; Bode et al. 1998; } \\
\text { Brown et al. 2001; Garcia et al. } \\
\text { 2006; Cataldo et al. 2004; Dore, } \\
\text { Bilotta et al. 1999; Begue et al. 1998) }\end{array}$ & $\begin{array}{l}\text { Largely dependable on the } \\
\text { animal and location } \\
\text { studied (see main text). }\end{array}$ & $\begin{array}{l}\text { (Imamura et al. 2003; } \\
\text { Grubel et al. 1997; } \\
\text { Osato et al. 1998) }\end{array}$ \\
\hline Water & $13(76 \%)$ & $\begin{array}{l}\text { (Garcia et al. 2006; Goodman et al. } \\
\text { 1996; Ilboudo et al. 1998; Yamashita } \\
\text { et al. 2001; Lin et al. 1999; Lindo } \\
\text { et al. 1999; Jimenez-Guerra, Shetty, } \\
\text { and Kurpad 2000; Olmos et al. 2000; } \\
\text { Herbarth et al. 2001; Lyra et al. } \\
\text { 2003; Klein et al. 1991; Begue et al. } \\
\text { 1998; Aguemon et al. 2005; } \\
\text { Al-Shamahy 2005; Iso, Matsuhisa, } \\
\text { and Shimizu 2005; Ahmed et al. } \\
\text { 2006; Mitipat et al. 2005) }\end{array}$ & $\begin{array}{l}\text { Survival depends on } \\
\text { temperature. At } 4^{\circ} \mathrm{C} \text { it } \\
\text { remains culturable for } \\
20-25 \text { days; at } 15^{\circ} \mathrm{C} \text { for } \\
10-15 \text { days and at } 24^{\circ} \mathrm{C} \\
\text { for 6-10 hours. }\end{array}$ & $\begin{array}{l}\text { (Shahamat et al. 1993; } \\
\text { Azevedo et al. 2004; } \\
\text { Adams, Bates, and } \\
\text { Oliver 2003) }\end{array}$ \\
\hline Food & $6(75 \%)^{d}$ & $\begin{array}{l}\text { (Goodman et al. 1996; Ilboudo et al. } \\
\text { 1998; Russo et al. 1999; Constanza } \\
\text { et al. 2004; Turkdogan et al. 2005; } \\
\text { Hopkins et al. 1993; Begue et al. } \\
\text { 1998; Ahmed et al. 2006) }\end{array}$ & $\begin{array}{l}\text { Largely dependable on the } \\
\text { type of food (see main } \\
\text { text) }\end{array}$ & $\begin{array}{l}\text { (Gomes and De } \\
\text { Martinis 2004; Poms } \\
\text { and Tatini 2001) }\end{array}$ \\
\hline
\end{tabular}

${ }^{a}$ By positive association we consider studies where the impact of factors related to the transmission pathway were statistically significant.

${ }^{b}$ Because epidemiological data on effective transmission of $H$. pylori to patients is scarce, studies addressing the contamination of medical staff from gastrointestinal endoscopy units were also included.

${ }^{c}$ As assessed by cultivability methods, which might in fact underestimate the true survival time of the bacterium.

${ }^{d}$ Discrimination between animals and types of food can be found in the main text.

${ }^{e}$ Epidemiological studies consistently point to domestic overcrowding and infection of family members (or similar) as a risk factor for $H$. pylori acquisition. 
acquisition of $H$. pylori, but the extent of this support depends on the animals under study. Considered vectors include cows (Fujimura et al. 2002), sheep (Dore et al. 2001), cockroaches (Imamura et al. 2003), houseflies (Osato et al. 1998), and domestic pets (Boomkens et al. 2004).

In the first two cases, the suspected route of transmission is mainly by the ingestion of contaminated raw milk. Milk could become contaminated when the breast of a cow or sheep is in contact with feces in the soil. Epidemiologic data has shown higher prevalence in shepherds and their families than in the general population (Dore et al. 1999; Plonka et al. 2006). The detection of the bacterium in animal milk is described ahead (see food ingestion section).

Inamura et al. (Imamura et al. 2003) suggested that cockroaches, which usually live in unsanitary environments, may contaminate foods and food containment areas such as pantries. The authors studied the survival of $H$. pylori on the external surfaces (legs and body) and excreta of H. pylori-exposed cockroaches and found that the microorganism was culturable from the excreta of the exposed group for $24 \mathrm{~h}$ postchallenge, but not from the external surfaces. A similar study was also performed with houseflies (Grubel et al. 1997). In this case, $H$. pylori was recovered from external surfaces for up to $12 \mathrm{~h}$ and from gut and excreta for as long as $30 \mathrm{~h}$ postchallenge. The negative detection after $30 \mathrm{~h}$ was attributed to the appearance of other Gram-negative bacteria that overgrew the cultures. However, when this study was repeated exposing the houseflies to $H$. pylori-contaminated human feces instead of $H$. pylori grown on agar plates, the microorganism was not cultured from any of the locations (Osato et al. 1998).

Epidemiological studies showed controversial results in respect to the risk of the presence of domestic animals in the household (Table 1) (e.g., Bode et al. 1998; Lindo et al. 1999; Kearney and Crump 2002). H. pylori has not been found in dogs and only very rarely in cats' stomachs (ElZaatari et al. 1997; Neiger and Simpson 2000), and it has been suggested that the presence in animals is of human origin (Cittelly et al. 2002; ElZaatari et al. 1997). Recent work has identified H. pylori by PCR in the bile of cats, thus increasing the chance of this animal as a vector (Boomkens et al. 2004). It is now known that nearly each animal is colonized by its own endogenous Helicobacter spp. Like H. pylori, that has co-evolved with humans to be highly specialized in the colonization of the human GI tract (Falush et al. 2003), these bacteria have specialized in colonizing the GI tract of their specific natural host. In the model where only one strain colonizes the stomach of a mammal, H. pylori would find fierce competition by these other Helicobacter spp. in search for essential nutrients and not subsist. With the emergence of a multiple infecting strains and species model for the same host it is more credible that $H$. pylori is also a zoonotic agent.

\section{Water Ingestion}

A large number of epidemiological studies have investigated drinking water, or drinking water-related conditions, as a risk factor for $\mathrm{H}$. pylori infection (Table 1). Although a few studies report the absence of an association between prevalence of $H$. pylori and water quality, the majority of the other studies support a relationship between these parameters.

Concomitantly, molecular methods such as FISH, PCR and antibody assays, were able to detect the presence of the bacterium in water and water-associated biofilms from wells, rivers and water distribution networks (e.g., Bragança et al. 2005; Piqueres et al. 2006; Fujimura, Kato, and Kawamura 2004). However, when suspended in water, $H$. pylori has a very low culturability time when compared to other waterborne pathogens. In fact, several studies report culturability times of less than 10 hours for H. pylori (Adams, Bates, and Oliver 2003; Azevedo et al. 2004; Shahamat et al. 1993) at temperatures over $20^{\circ} \mathrm{C}$ which compares to culturability times of more than 40 days for Escherichia coli and Salmonella typhimurium at the same temperature. While $H$. pylori culturability usually ends after little time in water and water-exposed biofilms (Azevedo, Pacheco et al. 2006; Azevedo, Pinto et al. 2006), Shahamat et al. (Shahamat et al. 1993) determined that total cell counts did not decrease for much longer periods $\left(2\right.$ years at $4{ }^{\circ} \mathrm{C}$ ). This raises questions on the exact physiological state of the bacterium in water and in the evaluation of methods that could be more appropriate for the detection of the infectious microorganism. For instance, a nutrient shock effect was also observed when recovering the waterstressed bacterium to high nutrient medium, showing some level of $H$. pylori adaptation to this environment (Azevedo et al. 2004). Furthermore, it has been attempted to demonstrate that coccoid (cell shape associated with non-culturability) $H$. pylori induced by water is capable of colonizing the gastric mucosa and cause gastrititis in mice (She et al. 2003; Cellini et al. 1994).

\section{Food Ingestion}

At least two epidemiological studies have found a positive relationship between the consumption of uncooked vegetables and H. pylori transmission (Hopkins et al. 1993; Goodman et al. 1996). Raw vegetables are suspected to be vulnerable to $H$. $p y$ lori colonization when contaminated water is used for washing or irrigation. It is important to bear in mind that this route assumes that $H$. pylori is also able to survive in water and has therefore all the problems associated with this possible transmission route. No reports have been found about cultivation methods or molecular biology procedures trying to detect the microorganism from these products. Survival studies indicate that inoculated $\mathrm{H}$. pylori (temperature: $8^{\circ} \mathrm{C}$; inoculation density $\approx 10^{6}-10^{7} \mathrm{CFU} / \mathrm{g}$ ) dropped below detection limits at 4 days in sanitized lettuce and carrot samples, and at 5 days in sterilized carrot (Gomes and De Martinis 2004). In a different study, survival of the microorganism lasted for up to 2 days in leaf lettuce $\left(4^{\circ} \mathrm{C} ; \approx 10^{2} \mathrm{CFU} / \mathrm{g}\right)$ (Poms and Tatini 2001).

Milk is another type of food implicated as a possible transmission vehicle by epidemiological studies. Constanza et al. correlated infection with the intake of milk products in Mexico (Constanza et al. 2004). Conversely, an epidemiological study in 
Italy reported an inverse correlation between the elevated consumption of milk and H. pylori prevalence (Russo et al. 1999). The differences obtained in both studies might reflect variable milk microbiological quality between these two countries. Interestingly, a recent study in Poland showed that prevalence in shepherds and their families was $20-30 \%$ higher than in farmers with no contact to sheep (Papiez et al. 2003). They understandably attributed this difference to the contact with animals (zoonosis), but failed to consider a probably higher quantity ingestion of raw milk by the shepherds and their families as a variable. Previously, in 1999, Dore et al. found similar results in a community of Sardinian shepherds and their families (Dore, Bilotta et al. 1999), but the research group went on to try and detect $H$. pylori presence in sheep milk. They were able to report the recovery of viable $H$. pylori from raw milk samples on two separate occasions (Dore, Sepulveda et al. 1999; Dore et al. 2001), but failed to confirm the survival of the microorganism after pasteurization of the milk. Furthermore, a larger screening of 400 raw sheep milk samples performed in Turkey detected no viable H. pylori (Turutoglu and Mudul 2002). The pathogen has also been cultured from one sample of raw cow's milk in Japan (Fujimura et al. 2002), and in the same work PCR demonstrated the presence of the ureA gene of $H$. pylori in 13 of 18 (72.2\%) raw milk samples and in 11 of $20(55 \%)$ commercial pasteurized milk samples.

Poms and Tatini studied the survival of $H$. pylori in other commercially available food products, such as yoghurt, chicken meat and tofu (Poms and Tatini 2001). The bacterium was cultured for 1,2 , and 7 days, respectively $\left(4^{\circ} \mathrm{C} ; \approx 10^{2} \mathrm{CFU} / \mathrm{g}\right)$. Differences in the culturability could be explained by the work of Jiang and Doyle (Jiang and Doyle 1998), who, based on the effect of environmental and substrate factors on survival and growth of $H$. pylori, have stated that the microorganism usually exhibits extended survival in low acid/high moisture environments. Also, autochthonous microbiota present in the yoghurt, such as Lactobacillus and Bifidobacterium, have been shown to inhibit the survival of $H$. pylori (Wang et al. 2004; Wendakoon and Ozimek 2002).

\section{LIKELIHOOD TO CAUSE INFECTION FOR EACH TRANSMISSION PATHWAY}

The most notorious elements to be taken from the data presented in Table 1 are perhaps the amount of epidemiological evidence that appears to support all routes of transmission but breastfeeding. Even with the obvious pitfalls with this type of analysis, which include the possible existence of confounding factors not accounted for in some of the studies and the natural tendency to give relevance and present data that are significant rather than data that are not, the case for a multi-route way of transmission is compelling.

On the other hand, there is a lack of standardized microbiological plating studies for nearly all pathways. Increasing temperatures are an important factor for reducing $H$. pylori culturability in water systems, and it is likely that this effect will be observed for other microenvironments. This temperature effect partly explains why $H$. pylori has not been regularly found in the oral cavity or human feces. The relationship between culturability and effective survival of the microorganism is also yet to be fully determined, but the small number of studies available so far indicate that the latter appears to prevail for much longer than the first (She et al. 2003; Cellini et al. 1994). Once again, this information supports a role for environmental reservoirs.

But other arguments exist. Unlike for Helicobacter spp., infection with certain Campylobacter species usually induces rapid (2-5 days depending on several factors) alterations in the health of a host, causing diarrhea, abdominal pain, and fever (Moore et al. 2005; Butzler 2004). Furthermore, plating techniques have been evolving for a longer time, which implies that more effective culture media and selective supplements have already been developed (Butzler 2004). Consequently, when large outbreaks occur, researchers have systematically been able to trace back the infections to the source of contamination. With the phylogenetical proximity between both species, it should be expected that, at least in part, the behavior of both bacteria in respect to transmission could be similar, but unless $H$. pylori is indeed capable of at least limited survival in the environment, this would not hold true. In fact, Campylobacter spp. have long been known for being able to survive in the environment, and a recent tentative estimative on how much each route contribute to infection has estimated that $44.3 \%$ of the infections in humans were derived from livestock and the remaining from other reservoirs (Champion et al. 2005).

It is widely assumed that $H$. pylori uses genetic variation to adapt to individual hosts and specific niches within a host (Kraft et al. 2006; Kang and Blaser 2006; Suerbaum et al. 1998), and that a large proportion of temporal genomic changes within $H$. pylori are the result of intergenomic recombination (Kraft et al. 2006). It can therefore be concluded that continuous exposure to new strains is necessary for generating genomic changes in $H$. pylori. As it has been shown that the bacterium is able to retain cell integrity for at least two years in water at low temperatures, it seems very possible that the environment could serve as the main pool of genetic diversity for $H$. pylori.

In a multi-route transmission scenario, the higher contributor to prevalence is likely to be the gastro-oral transmission, as vomitus and surrounding air are the only samples from where the bacterium is able to be consistently cultured and isolated. The route classically favors spread in small units of interacting people such as families, but modern facilities such as nurseries would presumably affect prevalence (Blaser 1999). If transmission was mainly airborne, the improved cleaning procedures in these institutions would have little effect in controlling infection, leading to an increase in prevalence at some time point during the last century. As this has not been the case, we are left with direct contact with vomitus (which would be affected by improved cleaning procedures) to account for the observed decrease. Epidemiological evidence supports the view that gastro-oral is the 


\section{Developed countries}

Generation 0

Generation 1
Generation 2

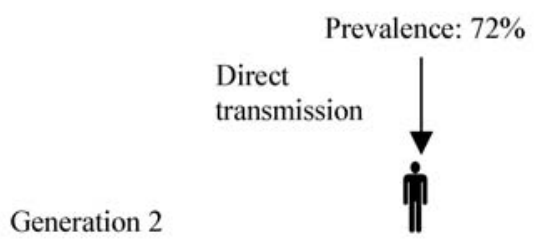

Prevalence: $57.6 \%$

\section{Underdeveloped countries}
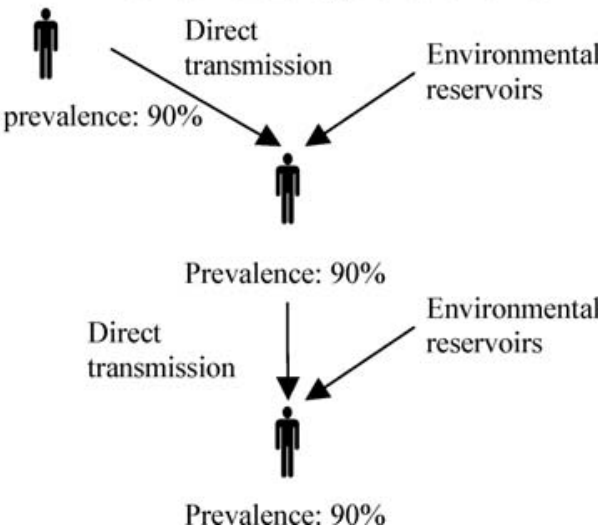

FIG. 3. Assuming that $80 \%$ of all H. pylori transmissions are caused by direct person-to-person contact and that the remaining $20 \%$ are caused by environmental reservoirs (either by direct infection or by maintaining strain diversity), it would only take two generations to drop from the baseline prevalence of $90 \%$ to a prevalence of $57.6 \%$. For generations 3, 4, and 5, the values decrease to $46.1 \%, 36.9 \%$, and $29.5 \%$, respectively. It is important to notice however that only in particular situations would the environmental contribution decrease directly from $20 \%$ to $0 \%$.

main route of transmission (Perry et al. 2006), but confirmatory studies on this issue are needed.

As gastro-oral transmission is not accountable for all cases of H. pylori infection, then the issue of why researchers have failed to consistently culture the bacterium outside the human GI tract has to be addressed. This situation may be attributable to either one of the following: fastidious nature of $H$.pylori; complexity of the heterotrophic microflora together with the lack of a suitable selective supplement; entry of the bacterium in the VBNC state; and the timing when sampling is performed. In either case, there are little factual differences between the fecal-oral and oral-oral route. Both are likely contributors to $H$. pylori infection but at a lower scale. On the other hand, both iatrogenic and breastfeeding appear to have at most, only residual contributions to increased prevalence.

As for environmental reservoirs, all evidence described above point that it is likely that they play a role. However, the estimates of $10^{4} \mathrm{H}$. pylori cells for primary infection to occur is probably a very large bacterial load for $H$. pylori coming from water or food (Solnick et al. 2001), especially if we bear in mind that the bacterium has little tendency to aggregate under most environmental conditions (Azevedo, Pacheco et al. 2006; Azevedo, Pinto et al. 2006). In addition, as H.pylori remains culturable for longer at lower temperatures, it should be expected that colder areas would present higher infection rates and that transmission would mostly occur during winter, which is not the case. Therefore, direct infection by environmental reservoirs could be mostly attributed to zoonotic transmission. Nevertheless, water and food might have a much more subtle effect on prevalence. In this new scenario, the human body is able to recognize and fight off most attempts to colonize the human GI tract from environmental $H$. pylori, by a conjugation of three factors: low numbers of the bacterium; low physiological activity; and possibly by host resistance to most strains. Environmental reservoirs as contributors to prevalence would act however by providing a pool of genetic material, during transient passages through the GI tract, that promote the diversity of the bacterium and hence the ability to colonize all different niches in the stomach and also different individuals. With the increasing control of water parameters and food quality observed during the last century, this scenario would be able to explain the decline of $H$. pylori colonization in the developed countries (Figure 3).

\section{CONCLUSIONS}

Experience teaches that when there is a lot of conflicting evidence in one area, either the answer lies beyond the explanations advanced so far, or there is more than one correct explanation. As such, and assuming that the real answer has not escaped our attention, we suggest a hybrid solution where several routes contribute to the prevalence levels of $H$. pylori in the human population. In this scenario direct person-to-person infection (mainly including oral-oral, gastro-oral, and fecal-oral transmission) are the main contributors, together with possibly zoonotic transmission, in terms of successful colonization of the human host. The importance of food and water is mainly in terms of conserving enough genetic diversity to allow for $H$. pylori to co-evolve with humans and maintain a persistent equilibrium, a concept that is supported by mathematical modelling (Blaser and Kirschner 1999).

During the writing of this review, other valid solutions that can explain the apparent discrepancy between levels of infection in developed vs. underdeveloped countries have been evident. For instance, the classical theory where improved levels of hygiene and lower density of living in the household might still be the real reason why prevalence is receding, as is an increased resistance of human hosts to $H$. pylori due to improved diets or antibiotics intake. The model presented here should therefore not rule out the possibility of these being true, nor should it be regarded as the final solution. Nevertheless, providing it with an underlying 
mathematical basis would be useful both as a confirmation and as a way of predicting future trends in prevalence.

\section{REFERENCES}

Adams, B.L., Bates, T.C., and Oliver, J.D. 2003. Survival of Helicobacter pylori in a natural freshwater environment. Applied and Environmental Microbiology 69(12), 7462-7466.

Aguemon, B.D., Struelens, M.J., Massougbodji, A., and Ouendo, E.M. 2005. Prevalence and risk-factors for Helicobacter pylori infection in urban and rural Beninese populations. Clinical Microbiology and Infection 11(8), 611617.

Ahmed, K.S., Khan, A.A., Ahmed, I., Tiwari, S.K., Habeeb, M.A., Ali, S.M., Ahi, J.D., Abid, Z., Alvi, A., Hussain, M.A., Ahmed, N., and Habibullah. C.M. 2006. Prevalence study to elucidate the transmission pathways of Helicobacter pylori at oral and gastroduodenal sites of a South Indian population. Singapore Med J 47(4), 291-296.

Al-Shamahy, H.A. 2005. Seroprevalence of Helicobacter pylori among children in Sana'a, Yemen. Ann. Saudi. Med. 25(4), 299-303.

Andersen, L.P., and Wadstrom, T. 2001. Basic bacteriology and culture. In Helicobacter pylori: physiology and genetics, edited by Mobley, H.L.T., Mendz, G. L., and Hazell. S.L. Washington, D. C.: ASM press.

Azevedo, N.F., Pacheco, A.P., Keevil, C.W., and Vieira, M.J. 2006. Adhesion of water stressed Helicobacter pylori to abiotic surfaces. Journal of Applied Microbiology 101(3), 718-724.

Azevedo, N.F., Pacheco, A.P., Vieira, M.J., and Keevil, C.W. 2004. Nutrient shock and incubation atmosphere influence recovery of culturable Helicobacter pylori from water. Applied and Environmental Microbiology 70(1), 490493.

Azevedo, N.F., Pinto, A.R., Reis, N.M., Vieira, M.J., and Keevil, C.W. 2006. Shear stress, temperature, and inoculation concentration influence the adhesion of water-stressed Helicobacter pylori to stainless steel 304 and polypropylene. Applied and Environmental Microbiology 72(4), 2936-2941.

Bakka, A.S., and Salih, B.A. 2002. Prevalence of Helicobacter pylori infection in asymptomatic subjects in Libya. Diagnostic Microbiology and Infectious Disease 43(4), 265-268.

Begue, R.E., Gonzales, J.L., Correa-Gracian, H., and Tang, S.C. 1998. Dietary risk factors associated with the transmission of Helicobacter pylori in Lima, Peru. American Journal of Tropical Medicine and Hygiene 59(4), 637-640.

Blaser, M.J. 1999. Where does Helicobacter pylori come from and why is it going away? Journal of the American Medical Association 282(23), 2260-2262.

Blaser, M.J., and Atherton, J.C. 2004. Helicobacter pylori persistence: biology and disease. Journal of Clinical Investigation 113(3), 321-333.

Blaser, M.J., and Kirschner, D. 1999. Dynamics of Helicobacter pylori colonization in relation to the host response. Proceedings of the National Academy of Sciences of the United States of America 96(15), 8359-8364.

Blecker, U., Lanciers, S., Keppens, E., and Vandenplas, Y. 1994. Evolution of Helicobacter pylori positivity in infants born from positive mothers. J. Pediatr. Gastroenterol. Nutr. 19(1), 87-90.

Bode, G., Rothenbacher, D., Brenner, H., and Adler, G. 1998. Pets are not a risk factor for Helicobacter pylori infection in young children: results of a population-based study in Southern Germany. Pediatric Infectious Disease Journal 17(10), 909-912.

Bohr, U.R.M., Selgrad, M., Ochmann, C., Backert, S., Konig, W., Fenske, A., Wex, T., and Malfertheiner, P. 2006. Prevalence and spread of enterohepatic Helicobacter species in mice reared in a specific-pathogen-free animal facility. Journal of Clinical Microbiology 44(3), 738-742.

Boomkens, S.Y., Kusters, J.G., Hoffmann, G., Pot, R.G.J., Spee, B., Penning, L.C., Egberink, H.F., van den Ingh, T.S.G.A.M., and Rothuizen, J. 2004. Detection of Helicobacter pylori in bile of cats. Fems Immunology and Medical Microbiology 42(3), 307-311.

Boyanova, L., Andrew, N., Bouchard, S., and Megraud. F. 1994. HelicobacterPylori Seroprevalence in Bulgaria. Medical Microbiology Letters 3(3), 107113.
Bragança, S.M., Azevedo, N.F., Simões, L., Vieira, M.J., and Keevil, C.W. 2005. Detection of Helicobacter pylori in biofilms formed in a real drinking water distribution system using peptide nucleic acid fluorescence in situ hybridization. In Biofilms: Persistence and Ubiquity, edited by A. McBain, D. Allison, J. Pratten, D. Spratt, M. Upton and Verran. J. Manchester: Biofilm Club.

Brown, L.M. 2000. Helicobacter pylori: epidemiology and routes of transmission. Epidemiol. Rev. 22(2), 283-297.

Brown, L.M., Osato, M., You, W.C., El-Zimaity, H., Li, J.Y., Zhang, L.A., and Gail, M.H. 2005. Disinfection of endoscopes from Helicobacter pyloripositive subjects: Evaluation of the effectiveness of the Chinese Calijing disinfection kit. American Journal of Infection Control 33(4), 197-201.

Brown, L.M., Thomas, T.L., Ma, J.L., Chang, Y.S., You, W.C., Liu, W.D., Zhang, L., and Gail, M.H. 2001. Helicobacter pylori infection in rural China: Exposure to domestic animals during childhood and adulthood. Scandinavian Journal of Infectious Diseases 33(9), 686-691.

Bumann, D., Habibi, H., Kan, B., Schmid, M., Goosmann, C., Brinkmann, V., Meyer, T.F., and Jungblut, P.R. 2004. Lack of stage-specific proteins in coccoid Helicobacter pylori cells. Infection and Immunity 72(11), 67386742 .

Butzler, J.P. 2004. Campylobacter, from obscurity to celebrity. Clinical Microbiology and Infection 10(10), 868-876.

Carrillo, B.G. 2005. Prevalence of Helicobacter pylori infection in Santo Domingo. Helicobacter 10(5), 488-488.

Carrillo, B.G., Vidal, T., Valmana, C., Camou, C., Santos, A., Megraud, F., Gonzalez, N., Leonard, L., Martinez, R., and Diaz-Canel, O. 2005. Helicobacter pylori infection in Havana, Cuba. Prevalence and cagA status of the strains. Helicobacter 10(5), 486-486.

Cataldo, F., Simpore, J., Greco, P., Ilboudo, D., and Musumeci, S. 2004. Helicobacter pylori infection in Burkina Faso: an enigma within an enigma. Digestive and Liver Disease 36(9), 589-593.

Cellini, L., Allocati, N., Angelucci, D., Iezzi, T., Dicampli, E., Marzio, L., and Dainelli, B. 1994. Coccoid Helicobacter-Pylori Not Culturable in-Vitro Reverts in Mice. Microbiology and Immunology 38(11), 843-850.

Champion, O.L., Gaunt, M.W., Gundogdu, O., Elmi, A., Witney, A.A., Hinds, J., Dorrell, N., and Wren, B.W. 2005. Comparative phylogenomics of the foodborne pathogen Campylobacter jejuni reveals genetic markers predictive of infection source. Proceedings of the National Academy of Sciences of the United States of America 102(44), 16043-16048.

Chaput, C., Ecobichon, C., Cayet, N., Girardin, S.E. C. Werts, S. Guadagnini, Prevost, M.C., Mengin-Lecreulx, D., Labigne, A., and Boneca, I.G. 2006. Role of AmiA in the Morphological Transition of Helicobacter pylori and in Immune Escape. PLoS Pathog 2(9).

Cittelly, D.M., Dore, M.P., Bravo, M.M., Monsalve, H., Botero, R., Ricaurte, O., Yamaoka, Y., El-Zimaity, H.M.T., Osato, M.S., Fox, J.G., Realdi, G., and Graham, D.Y. 2002. Helicobacter pylori in animals is of human origin: studies in monkey's, sheep, and cats. Gut 51, A31-A31.

Con, S.A., Valerin, A.L., Takeuchi, H., Con-Wong, R., Con-Chin, V.G., ConChin, G.R., Yagi-Chaves, S.N., Mena, F., Pino, F.B., Echandi, G., Kobayashi, M., Monge-Izaguirre, M., Nishioka, M., Morimoto, N., Sugiura, T., and Araki, K. 2006. Helicobacter pylori CagA status associated with gastric cancer incidence rate variability in Costa Rican regions. Journal of Gastroenterology 41(7), 632-637.

Constanza, C.M., Eduardo, L.P., Javier, T., Eduardo, V.M., Manuel, Q., and Pelayo, C. 2004. Determinants of Helicobacter pylori seroprevalence in Mexican adolescents. Helicobacter 9(2), 106-114.

Cronmiller, J.R., Nelson, D.K., Jackson, D.K., and Kim, C.H. 1999. Efficacy of conventional endoscopic disinfection and sterilization methods against Helicobacter pylori contamination. Helicobacter 4(3), 198-203.

Daugule, I., Rumba, I., Engstrand, L., and Ejderhamn, J. 2003. Infection with cagA-positive and cagA-negative types of Helicobacter pylori among children and adolescents with gastrointestinal symptoms in Latvia. European Journal of Clinical Microbiology \& Infectious Diseases 22(10), 622-624.

De Gusmao, V.R., Mendes, E.N., Queiroz, D.M.D., Rocha, G.A., Rocha, A.M.C., Ashour, A.A.R., and Carvalho, A.S.T. 2000. vacA genotypes in Helicobacter pylori strains isolated from children with and without 
duodenal ulcer in Brazil. Journal of Clinical Microbiology 38(8), 28532857.

Delport, W., Cunningham, M., Olivier, B., Preisig, O., and van der Merwe, S.W. 2006. A population genetics pedigree perspective on the transmission of Helicobacter pylori. Genetics 174(4), 2107-2118.

Dore, M.P., Bilotta, M., Vaira, D., Manca, A., Massarelli, G., Leandro, G., Atzei, A., Pisanu, G., Graham, D.Y., and Realdi, G. 1999. High prevalence of Helicobacter pylori infection in shepherds. Digestive Diseases and Sciences 44(6), 1161-1164.

Dore, M.P., Sepulveda, A.R., El-Zimaity, H., Yamaoka, Y., Osato, M.S., Mototsugu, K., Nieddu, A.M., Realdi, G., and Graham, D.Y. 2001. Isolation of Helicobacter pylori from sheep-Implications for transmission to humans. American Journal of Gastroenterology 96(5), 1396-1401.

Dore, M.P., Sepulveda, A.R., Osato, M.S., Realdi, G., and Graham, D.Y. 1999. Helicobacter pylori in sheep milk. Lancet 354(9173), 132-132.

Dowsett, S.A., and Kowolik, M.J. 2003. Oral Helicobacter pylori: Can we stomach it? Critical Reviews in Oral Biology \& Medicine 14(3), 226-233.

ElZaatari, F.A.K., Woo, J.S., Badr, A., Osato, M.S., Serna, H., Lichtenberger, L.M., Genta, R.M., and Graham, D.Y. 1997. Failure to isolate Helicobacter pylori from stray cats indicates that H-pylori in cats may be an anthroponosisAn animal infection with a human pathogen. Journal of Medical Microbiology 46(5), 372-376.

Erreimi, N., Mouane, N., Hajarabi, S., Alhamani, Z., and Bouchta, F. 1999. Helicobacter pylori gastritis in children. Experience with 230 gastric biopsies performed at the Rabat pediatric hospital. Annales De Pediatrie 46(7), 445451.

Ertem, D., Harmanci, H., and Pehlivanoglu, E. 2003. Helicobacter pylori infection in Turkish preschool and school children: role of socioeconomic factors and breast feeding. Turkish Journal of Pediatrics 45(2), 114-122.

Falush, D., Wirth, T., Linz, B., Pritchard, J.K., Stephens, M., Kidd, M., Blaser, M.J. Graham, D.Y., Vacher, S., Perez-Perez, G.I., Yamaoka, Y., Megraud, F., Otto, K., Reichard, U., Katzowitsch, E., Wang, X.Y., Achtman, M., and Suerbaum, S. 2003. Traces of human migrations in Helicobacter pylori populations. Science 299(5612), 1582-1585.

Figueiredo, C., Machado, J.C., and Yamaoka, Y. 2005. Pathogenesis of Helicobacter pylori infection. Helicobacter 10, 14-20.

Fox, J.G., Paster, B.J., Dewhirst, F.E., Taylor, N.S., Yan, L.L., Macuch, P.J., and Chmura, L.M. 1992. Helicobacter-Mustelae Isolation from $\mathrm{Fe}-$ ces of Ferrets-Evidence to Support Fecal-Oral Transmission of a Gastric Helicobacter. Infection and Immunity 60(2), 606-611.

Fritz, E.L., Slavik, T., Delport, W., Olivier, B., and van der Merwe, S.W. 2006. Incidence of Helicobacter felis and the effect of coinfection with Helicobacter pylori on the gastric mucosa in the African population. Journal of Clinical Microbiology 44(5), 1692-1696.

Fujimura, S., Kato, S., and Kawamura, T. 2004. Helicobacter pylori in Japanese river water and its prevalence in Japanese children. Lett. Appl. Microbiol. 38(6), 517-521.

Fujimura, S., Kawamura, T., Kato, S., Tateno, H., and Watanabe, A. 2002. Detection of Helicobacter pylori in cow's milk. Lett. Appl. Microbiol. 35(6), 504 507.

Garcia, R.M., Diz, P.G., Benavides, R.A.S., and Seara, J.F. 2006. Risk factors associated with Helicobacter pylori infection. A population-based study conducted in the province of Ourense. Revista Espanola De Enfermedades Digestivas 98(5), 330-336.

Ghose, C., Perez-Perez, G.I., van Doorn, L.J., Dominguez-Bello, M.G., and Blaser, M.J. 2005. High frequency of gastric colonization with multiple Helicobacter pylori strains in Venezuelan subjects. Journal of Clinical Microbiology 43(6), 2635-2641.

Goh, K.L., Parasakthi, N., and Ong, K.K. 1996. Prevalence of Helicobacter pylori infection in endoscopy and non-endoscopy personnel: Results of field survey with serology and C-14-urea breath test. American Journal of Gastroenterology 91(2), 268-270.

Gomes, B.C., and De Martinis, E.C.P. 2004. Fate of Helicobacter pylori artificially inoculated in lettuce and carrot samples. Brazilian Journal of Microbiology 35(1-2), 145-150.
Gomes, B.C., and De Martinis, E.C.P. 2004. The significance of Helicobacter pylori in water, food and environmental samples. Food Control 15(5), 397403.

Goodman, K.J., Correa, P., Tengana Aux, H.J., Ramirez, H., DeLany, J.P., Guerrero Pepinosa, O., Lopez Quinones, M., and Collazos Parra, T. 1996. Helicobacter pylori infection in the Colombian Andes: a population-based study of transmission pathways. Am J Epidemiol 144(3), 290-299.

Goodman, K.J., O’Rourke, K., Day, R.S., Wang, C., Nurgalieva, Z., Phillips, C.V., Aragaki, C., Campos, A., and de la Rosa, J.M. 2005. Dynamics of Helicobacter pylori infection in a US-Mexico cohort during the first two years of life. Int J Epidemiol 34(6), 1348-1355.

Grubel, P., Hoffman, J.S., Chong, F.K., Burstein, N.A., Mepani, C., and Cave, D.R. 1997. Vector potential of houseflies (Musca domestica) for Helicobacter pylori. J Clin Microbiol 35(6), 1300-1303.

Haggerty, T.D., Perry, S., Sanchez, L., Perez-Perez, G., and Parsonnet, J. 2005. Significance of transiently positive enzyme-linked immunosorbent assay results in detection of Helicobacter pylori in stool samples from children. Journal of Clinical Microbiology 43(5), 2220-2223.

Han, S.W., Evans, D.G., ElZaatari, F.A.K., Go, M.F., and Graham, D. 1996. The interaction of $\mathrm{pH}$, bile, and Helicobacter pylori may explain duodenal ulcer. American Journal of Gastroenterology 91(6), 1135-1137.

Hanninen, M.L. 1991. Sensitivity of Helicobacter-Pylori to Different Bile-Salts. European Journal of Clinical Microbiology \& Infectious Diseases 10(6), 515518.

Haukioja, A., Ihalin, R., Loimaranta, V., Lenander, M., and Tenovuo, J. 2004. Sensitivity of Helicobacter pylori to an innate defence mechanism, the lactoperoxidase system, in buffer and in human whole saliva. J. Med. Microbiol. 53(Pt 9), 855-860.

Herbarth, O., Krumbiegel, P., Fritz, G.J., Richter, M., Schlink, U., Muller, D.M., and Richter, T. 2001. Helicobacter pylori prevalences and risk factors among school beginners in a German urban center and its rural county. Environmental Health Perspectives 109(6), 573-577.

Hildebrand, P., Meyer-Wyss, B.M., Mossi, S., and Beglinger, C. 2000. Risk among gastroenterologists of acquiring Helicobacter pylori infection: casecontrol study. British Medical Journal 321(7254), 149-149.

Hoang, T.T.H., Bengtsson, C., Phung, D.C., Sorberg, M., and Granstrom, M. 2005. Seroprevalence of Helicobacter pylori infection in urban and rural Vietnam. Clinical and Diagnostic Laboratory Immunology 12(1), 8185.

Hoodeh, E., Azammi, A., Sarafnejad, A., Siavoshi, F., Masserrat, S., Safar, M., Dostkhah, N., Shariati, P., Astaraki, S., and Shahrestani, T. 2005. Seroprevalence of Helicobacter pylori infection in Tehran University students from 2001 to 2003. Helicobacter 10(5), 486-486.

Hopkins, R.J., Vial, P.A., Ferreccio, C., Ovalle, J., Prado, P., Sotomayor, V., Russell, R.G., Wasserman, S.S., and Morris, J.G. Jr. 1993. Seroprevalence of Helicobacter pylori in Chile: vegetables may serve as one route of transmission. J Infect Dis 168(1), 222-226.

Ilboudo, D., Sawadogo, A., Bougouma, A., Sombie, R., and Koueta, F. 1998. An epidemiologic study of Helicobacter pylori infection in children in Burkina Faso. Annales De Pediatrie 45(6), 425-429.

Imamura, S., Kita, M., Yamaoka, Y., Yamamoto, T., Ishimaru, A., Konishi, H., Wakabayashi, N., Mitsufuji, S., Okanoue, T., and Imanishi, J. 2003. Vector potential of cockroaches for Helicobacter pylori infection. American Journal of Gastroenterology 98(7), 1500-1503.

Iso, N., Matsuhisa, T., and Shimizu, K. 2005. Helicobacter pylori Infection among patients visiting a clinic in Kasama City, Ibaraki Prefecture. J. Nippon. Med. Sch. 72(6), 341-354.

Israel, D.A., Salama, N., Krishna, U., Rieger, U.M., Atherton, J.C., Falkow, S., and Peek, R.M. 2001. Helicobacter pylori genetic diversity within the gastric niche of a single human host. Proceedings of the National Academy of Sciences of the United States of America 98(25), 1462514630.

Jiang, X.P., and Doyle. M.P. 1998. Effect of environmental and substrate factors on survival and growth of Helicobacter pylori. Journal of Food Protection 61(8), 929-933. 
Jimenez-Guerra, F., Shetty, P., and Kurpad, A. 2000. Prevalence of and risk factors for helicobacter pylori infection in school children in Mexico. Annals of Epidemiology 10(7), 474.

Kabir, S. 2001. Detection of Helicobacter pylori in feces by culture, PCR and enzyme immunoassay. Journal of Medical Microbiology 50(12), 10211029.

Kang, J., and Blaser, M.J. 2006. Bacterial populations as perfect gases: genomic integrity and diversification tensions in Helicobacter pylori. Nature Reviews Microbiology 4(11), 826-836.

Katoh, M., Saito, D., Noda, T., Yoshida, S., Oguro, Y., Yazaki, Y., Sugimura, T., and Terada, M. 1993. Helicobacter-Pylori May Be Transmitted through Gastrofiberscope Even after Manual Hyamine Washing. Japanese Journal of Cancer Research 84(2), 117-119.

Kearney, D.J., and Crump, C. 2002. Domestic cats and cogs and home drinking water source as risk factors for Helicobacter pylori infection in the United States. Gut 51, A31-A32.

Khandaker, K., Palmer, K.R., Eastwood, M.A. Scott, A.C. Desai, M., and Owen, R.J. 1993. DNA Fingerprints of Helicobacter-Pylori from Mouth and Antrum of Patients with Chronic Ulcer Dyspepsia. Lancet 342(8873), 751-751.

Kikuchi, S., and Dore, M.P. 2005. Epidemiology of Helicobacter pylori infection. Helicobacter 10, 1-4.

Kitagawa, M., Natori, M., Katoh, M., Sugimoto, K., Omi, H., Akiyama, Y., and Sago, H. 2001. Maternal transmission of Helicobacter pylori in the perinatal period. J Obstet Gynaecol Res 27(4), 225-230.

Kivi, M., and Tindberg, Y. 2006. Helicobacter pylori occurrence and transmission: A family affair? Scandinavian Journal of Infectious Diseases 38(6-7), 407-417.

Klein, P.D., Graham, D.Y., Gaillour, A., Opekun, A.R., and Smith, E.O. 1991. Water source as risk factor for Helicobacter pylori infection in Peruvian children. Gastrointestinal Physiology Working Group. Lancet 337(8756), 15031506.

Koch, A., Krause, T.G., Krogfelt, K., Olsen, O.R., Fischer, T.K., and Melbye, M. 2005. Seroprevalence and risk factors for Helicobacter pylori infection in Greenlanders. Helicobacter 10(5), 433-442.

Kraft, C., Stack, A., Josenhans, C., Niehus, E., Dietrich, G., Correa, P., Fox, J.G., Falush, D., and Suerbaum, S. 2006. Genomic changes during chronic Helicobacter pylori infection. Journal of Bacteriology 188(1), 249254

Leung, W.K., Siu, K.L.K., Kwok, C.K.L., Chan, S.Y., Sung, R., and Sung, J.J.Y. 1999. Isolation of Helicobacter pylori from vomitus in children and its implication in gastro-oral transmission. American Journal of Gastroenterology 94(10), 2881-2884

Lin, D.B., Nieh, W.T., Wang, H.M., Hsiao, M.W., Ling, U.P., Changlai, S.P., Ho, M.S., You, S.L., and Chen, C.J. 1999. Seroepidemiology of Helicobacter pylori infection among preschool children in Taiwan. American Journal of Tropical Medicine and Hygiene 61(4), 554-558.

Lindo, J.F., Lyn-Sue, A.E., Palmer, C.J., Lee, M.G., Vogel, P., and Robinson, R.D. 1999. Seroepidemiology of Helicobacter pylori infection in a Jamaican community. Tropical Medicine \& International Health 4(12), 862-866.

Livingston, R.S., Riley, L.K., Besch-Williford, C.L., Hook, R.R., and Franklin, C.L. 1998. Transmission of Helicobacter hepaticus infection to sentinel mice by contaminated bedding. Laboratory Animal Science 48(3), 291-293.

Luman, W. 2002. Helicobacter pylori transmission: is it due to kissing? J.R. Coll. Physicians. Edinb. 32, 275-279.

Luman, W., Zhao, Y., Ng, H.S., and Ling, K.L. 2002. Helicobacter pylori infection is unlikely to be transmitted between partners: evidence from genotypic study in partners of infected patients. European Journal of Gastroenterology \& Hepatology 14(5), 521-528.

Lunet, N., and Barros, H. 2003. Helicobacter pylori infection and gastric cancer: Facing the enigmas. International Journal of Cancer 106(6), 953-960.

Lyra, A.C., Santana, G., Santana, N., Silvany-Neto, A., Magalhaes, E., Pereira, E.M., Mascarenhas, R., Lyra, M.C., Veiga, A., Ferreira, K., Zaterka, S., and Lyra, L.G. 2003. Seroprevalence and risk factors associated with Helicobacter pylori infection in blood donors in Salvador, Northeast-Brazil. Braz J. Infect. Dis. 7(5), 339-345.
Ma, J.L., You, W.C., Gail, M.H., Zhang, L., Blot, W.J., Chang, Y.S., Jiang, J., Liu, W.D., Hu, Y.R., Brown, L.M., Xu, G.W., and Fraumeni, J.F., Jr. 1998. Helicobacter pylori infection and mode of transmission in a population at high risk of stomach cancer. Int. J. Epidemiol. 27(4), 570-573.

Malaty, H.M., Logan, N.D., Graham, D.Y., and Ramchatesingh, J.E. 2001. Helicobacter pylori infection in preschool and school-aged minority children: Effect of socioeconomic indicators and breast-feeding practices. Clinical Infectious Diseases 32(10), 1387-1392.

Malfertheiner, P., Megraud, F., C. O’Morain, Bazzoli, F., E. El-Omar, Graham, D., Hunt, R., Rokkas, T., Vakil, N., and Kuipers, E. 2006. Current concepts in the management of Helicobacter pylori infection-The Maastricht III Consensus Report. Gut.

Mastromarino, P., Conti, C., Donato, K., Strappini, P.M., Cattaruzza, M.S., and Orsi, G.B. 2005. Does hospital work constitute a risk factor for Helicobacter pylori infection? Journal of Hospital Infection 60(3), 261-268.

Megraud, F. 1995. Transmission of Helicobacter-Pylori-Fecal-Oral Versus OralOral Route. Alimentary Pharmacology \& Therapeutics 9, 85-91.

Megraud, F. 2003. When and how does Helicobacter pylori infection occur? Gastroenterologie Clinique Et Biologique 27(3), 374-379.

Mitchell, H.M. 2001. Epidemiology of infection. In Helicobacter pylori: physiology and genetics, edited by Mobley, H.L.T., Mendz, G.L., and Hazell, S.L. Washington, DC: ASM press.

Mitchell, H.M., Li, Y.Y., Hu, P.J., Hazell, S.L., Du, G.G., Byrne, D.J., and Lee, A. 1992. The Susceptibility of Helicobacter-Pylori to Bile May Be an Obstacle to Fecal Transmission. European Journal of Gastroenterology \& Hepatology 4, S79-S83.

Mitipat, N., Siripermpool, P., Jadwattanakul, T., and Chaunthongkum, S. 2005. The prevalence of Helicobacter pylori infection in patients with gastrointestinal symptoms in Chon Buri, Thailand. Southeast Asian J. Trop. Med. Public Health 36(2), 341-346.

Moore, J.E., Corcoran, D., Dooley, J., S.G., Fanning, S., Lucey, B., Matsuda, M., McDowell, D.A., Megraud, F., Millar, B.C., O'Mahony, R., O'Riordan, L., O'Rourke, M., Rao, J.R., Rooney, P.J., Sails, A., and Whyte, P. 2005. Campylobacter. Veterinary Research 36(3), 351-382.

Ndip, R.N., Malange, A.E., Akoachere, J.F.T., MacKay, W.G., Titanji, V.P.K., and Weaver, L.T. 2004. Helicobacter pylori antigens in the feces of asymptomatic children in the Buea and Limbe health districts of Cameroon: a pilot study. Tropical Medicine \& International Health 9(9), 1036-1040.

Neiger, R., and Simpson, K.W. 2000. Helicobacter infection in dogs and cats: Facts and fiction. Journal of Veterinary Internal Medicine 14(2), 125 133.

Nguyen, B.V., Nguyen, K.G., Phung, C.D., Kremp, O., Kalach, N., Dupont, C., Raymond, J., and Vidal-Trecan, G. 2006. Prevalence of and factors associated with Helicobacter pylori infection in children in the north of Vietnam. American Journal of Tropical Medicine and Hygiene 74(4), 536-539.

Noone, P.A., Waclawski, E.R., and Watt, A.D. 2006. Are endoscopy nurses at risk of infection with Helicobacter pylori from their work? Occupational Medicine-Oxford 56(2), 122-128.

Notarnicola, M., Russo, F., Cavallini, A., Bianco, M., Jirillo, E., Pece, S., Leoci, C., diMatteo, G., and diLeo, A. 1996. PCR identification of Helicobacter pylori DNA in feces from patients with gastroduodenal pathology. Medical Science Research 24(11), 785-787.

Nugalieva, Z.Z., Opekun, A.R., and Graham, D.Y. 2006. Problem of distinguishing false-positive tests from acute or transient Helicobacter pylori infections. Helicobacter 11(2), 69-74.

Nurgalieva, Z.Z., Malaty, H.M., Graham, D.Y., Almuchambetova, R., Machmudova, A., Kapsultanova, D., Osato, M.S., Hollinger, F.B., and Zhangabylov, A. 2002. Helicobacter pylori infection in Kazakhstan: Effect of water source and household hygiene. American Journal of Tropical Medicine and Hygiene 67(2), 201-206.

Nurnberg, M., Schulz, H.J., Ruden, H., and Vogt, K. 2003. Do conventional cleaning and disinfection techniques avoid the risk of endoscopic Helicobacter pylori transmission? Endoscopy 35(4), 295-299.

Olivier, B.J., Bond, R.P., van Zyl, W.B., Delport, M., Slavik, T., Ziady, C., Droste, J.S.T.S., Lastovica, A., and van der Merwe, S.W. 2006. Absence of 
Helicobacter pylori within the oral cavities of members of a healthy South African community. Journal of Clinical Microbiology 44(2), 635-636.

Olmos, J.A., Rios, H., Higa, R., and Argentinean Hp Epidemiologic Study. 2000. Prevalence of Helicobacter pylori infection in Argentina-Results of a nationwide epidemiologic study. Journal of Clinical Gastroenterology 31(1), 33-37.

Osato, M.S., Ayub, K., Le, H.H., Reddy, R., and Graham, D.Y. 1998. Houseflies are an unlikely reservoir or vector for Helicobacter pylori. Journal of Clinical Microbiology 36(9), 2786-2788.

Papiez, D., Konturek, P.C., Bielanski, W., Plonka, M., Dobrzanska, M., Kaminska, A., Szczyrk, U., Bochenek, A., and Wierzchos, E. 2003. Prevalence of Helicobacter pylori infection in Polish shepherds and their families. Dig Liver Dis 35(1), 10-15.

Parsonnet, J., Shmuely, H., and Haggerty, T. 1999. Fecal and oral shedding of Helicobacter pylori from healthy infected adults. Journal of the American Medical Association 282(23), 2240-2245.

Pearce, M.S., Thomas, J.E., Campbell, D.I., and Parker, L. 2005. Does increased duration of exclusive breastfeeding protect against Helicobacter pylori infection? The Newcastle thousand families cohort study at age 4951 years. Journal of Pediatric Gastroenterology and Nutrition 41(5), 617620.

Perez-Perez, G.I., Rothenbacher, D., and Brenner, H. 2004. Epidemiology of Helicobacter pylori Infection. Helicobacter 9(Suppl 1), 1-6.

Perry, S., and Parsonnet, J. 2005. Commentary: H. pylori infection in early life and the problem of imperfect tests. Int. J. Epidemiol. 34(6), 1356-1358.

Perry, S., Sanchez, M.D.L., Yang, S.F., Haggerty, T.D., Hurst, P., G. Perez-Perez, and Parsonnet, J. 2006. Gastroenteritis and transmission of Helicobacter pylori infection in households. Emerging Infectious Diseases 12(11), 17011708.

Piqueres, P., Moreno, Y., Alonso, J.L., and Ferrus, M.A. 2006. A combination of direct viable count and fluorescent in situ hybridization for estimating Helicobacter pylori cell viability. Res Microbiol 157(4), 345-349.

Plonka, M., Bielanski, W., Konturek, S.J., Targosz, A., Sliwowski, Z., Dobrzanska, M., Kaminska, A., Sito, E., Konturek, P.C., and Brzozowski, T. 2006. Helicobacter pylori infection and serum gastrin, ghrelin and leptin in children of Polish shepherds. Digestive and Liver Disease 38(2), 9197.

Poms, R.E., and Tatini, S.R. 2001. Survival of Helicobacter pylori in ready-toeat foods at 4 degrees C. International Journal of Food Microbiology 63(3), 281-286.

Pounder, R.E., and Ng, D. 1995. The Prevalence of Helicobacter-Pylori Infection in Different Countries. Alimentary Pharmacology \& Therapeutics 9, 33 39.

Prinz, C., Hafsi, N., and Voland, P. 2003. Helicobacter pylori virulence factors and the host immune response: implications for therapeutic vaccination. Trends in Microbiology 11(3), 134-138.

Queiroz, D.M.M., and Luzza, F. 2006. Epidemiology of Helicobacter pylori infection. Helicobacter 11, 1-5.

Queralt, N., Bartolome, R., and Araujo, R. 2005. Detection of Helicobacter pylori DNA in human feces and water with different levels of fecal pollution in the north-east of Spain. Journal of Applied Microbiology 98(4), 889-895.

Rehnberg-Laiho, L., Rautelin, H., Koskela, P., Sarna, S., Pukkala, E., Aromaa, A., Knekt, P., and Kosunen, T.U. 2001. Decreasing prevalence of helicobacter antibodies in Finland, with reference to the decreasing incidence of gastric cancer. Epidemiology and Infection 126(1), 37-42.

Rodrigues, M.N., Queiroz, D.M.M., Braga, A.B.C., Rocha, A.M.C., Eulailo, E.C., and L. Braga, L.B.C. 2006. History of breastfeeding and Helicobacter pylori infection in children: results of a community-based study from northeastern Brazil. Transactions of the Royal Society of Tropical Medicine and Hygiene 100(5), 470-475.

Rodrigues, M.N., Queiroz, D.M.M., Filho, J.G.B., Pontes, L.K., Rodrigues, R.T., and L. Braga, L.B.C. 2004. Prevalence of Helicobacter pylori infection in children from an urban community in north-east Brazil and risk factors for infection. European Journal of Gastroenterology \& Hepatology 16(2), 201-205.

Roma-Giannikou, E., Karameris, A., Balatsos, B., Panayiotou, J., Manika, Z., C. Van-Vliet, Rokkas, T., Skandalis, N., and Kattamis, C. 2003. Intrafamilial Spread of Helicobacter pylori: A Genetic Analysis. Helicobacter 8(1), 15-20. Rothenbacher, D., Bode, G., Berg, G., Knayer, U., Gonser, T., Adler, G., and Brenner, H. 1999. Helicobacter pylori among preschool children and their parents: Evidence of parent-child transmission. Journal of Infectious Diseases 179(2), 398-402.

Rothenbacher, D., Bode, G., and Brenner, H. 2002. History of breastfeeding and Helicobacter pylori infection in pre-school children: results of a populationbased study from Germany. International Journal of Epidemiology 31(3), 632-637.

Russo, A., Eboli, M., Pizzetti, P., G. Di Felice, Ravagnani, F., Spinelli, P., Hotz, A.M., Notti, P., Maconi, G., Franceschi, S., Ferrari, D., and Bertario, L. 1999. Determinants of Helicobacter pylori seroprevalence among Italian blood donors. European Journal of Gastroenterology \& Hepatology 11(8), 867-873.

Shahamat, M., Mai, U., Paszkokolva, C., Kessel, M., and Colwell, R.R. 1993. Use of Autoradiography to Assess Viability of Helicobacter Pylori in Water. Applied and Environmental Microbiology 59(4), 1231-1235.

She, F.F., Lin, J.Y., Liu, J.Y., Huang, C., and Su, D.H. 2003. Virulence of waterinduced coccoid Helicobacter pylori and its experimental infection in mice. World J Gastroenterol 9(3), 516-520.

Solnick, J.V., and Schauer, D.B. 2001. Emergence of diverse Helicobacter species in the pathogenesis of gastric and enterohepatic diseases. Clinical Microbiology Reviews 14(1), 59-97.

Solnick, Jay V., Lori Hansen, M., Don Canfield, R., and Julie Parsonnet. 2001. Determination of the Infectious Dose of Helicobacter pylori during Primary and Secondary Infection in Rhesus Monkeys (Macaca mulatta). Infect. Immun. 69(11), 6887-6892.

Suerbaum, S., Smith, J.M., Bapumia, K., Morelli, G., Smith, N.H., Kunstmann, E., Dyrek, I., and Achtman, M. 1998. Free recombination within Helicobacter pylori. Proceedings of the National Academy of Sciences of the United States of America 95(21), 12619-12624.

Torres, M.A., Passaro, D.J., Watanabe, J., Parsonnet, J., Small, P., Miyagui, J., Rodriquez, C., Astete, M., and Gilman, R.H. 2003. No association between Helicobacter pylori and Mycobacterium tuberculosis infections among gastrointestinal clinic attendees in Lima, Peru. Epidemiology and Infection 130(1), 87-91.

Turkdogan, M.K., Akman, N., Tuncer, I., Uygan, I., Kosem, M., Ozel, S., Kara, K., Bozkurt, S., and Memik, F. 2005. Epidemiological aspects of endemic upper gastrointestinal cancers in Eastern Turkey. Hepato-Gastroenterology 52(62), 496-500.

Turutoglu, H., and Mudul, S. 2002. Investigation of Helicobacter pylori in raw sheep milk samples. J. Vet. Med. B. Infect. Dis. Vet. Public Health 49(6), 308 309.

Tytgat, G.N. J. 1995. Endoscopic Transmission of Helicobacter-Pylori. Alimentary Pharmacology \& Therapeutics 9, 105-110.

Van den Bulck, K., Decostere, A., Baele, M., Driesseu, A., Debongnie, J.C., Burette, A., Stolte, M., Ducatelle, R., and Haesebrouck, F. 2005. Identification of non-Helicobacter pylori spiral organisms in gastric samples from humans, dogs, and cats. Journal of Clinical Microbiology 43(5), 22562260.

Vollaard, A.M., Verspaget, H.W., Ali, S., Visser, L.G., Veenendaal, R.A., Van Asten, H.A.G.H., Widjaja, S., Surjadi, C., and Van Dissel, J.T. 2006. Helicobacter pylori infection and typhoid fever in Jakarta, Indonesia. Epidemiology and Infection 134(1), 163-170.

Wang, K.Y., Li, S.N., Liu, C.S., Perng, D.S., Su, Y.C., Wu, D.C., Jan, C.M., Lai, C.H., Wang, T.N., and Wang, W.M. 2004. Effects of ingesting Lactobacillusand Bifidobacterium-containing yogurt in subjects-with colonized Helicobacter pylori. American Journal of Clinical Nutrition 80(3), 737741. 
Wendakoon, C.N., and Ozimek, L. 2002. Inhibition of Helicobacter pylori growth by Lactobacillus casei in fermented milk. Milchwissenschaft-Milk Science International 57(9-10), 506-509.

Wu, M.S., Wang, J.T., Yang, J.C., Wang, H.H., Sheu, J.C., Chen, D.S., and Wang, T.H. 1996. Effective reduction of Helicobacter pylori infection after upper gastrointestinal endoscopy by mechanical washing of the endoscope. Hepato-Gastroenterology 43(12), 1660-1664.
Yamashita, Y., Fujisawa, T., Kimura, A., and Kato, H. 2001. Epidemiology of Helicobacter pylori infection in children: A serologic study of the Kyushu region in Japan. Pediatrics International 43(1), 4-7.

Young, K.A., Akyon, Y., Rampton, D.S., Barton, S.G.R.G., Allaker, R.P., Hardie, J.M., and Feldman, R.A. 2000. Quantitative culture of Helicobacter pylori from gastric juice: the potential for transmission. Journal of Medical Microbiology 49(4), 343-347. 